University of Nebraska - Lincoln

DigitalCommons@University of Nebraska - Lincoln

\title{
Spatial and Temporal Variability in the Amount and Source of Dissolved Organic Carbon: Implications for Ultraviolet Exposure in Amphibian Habitats
}

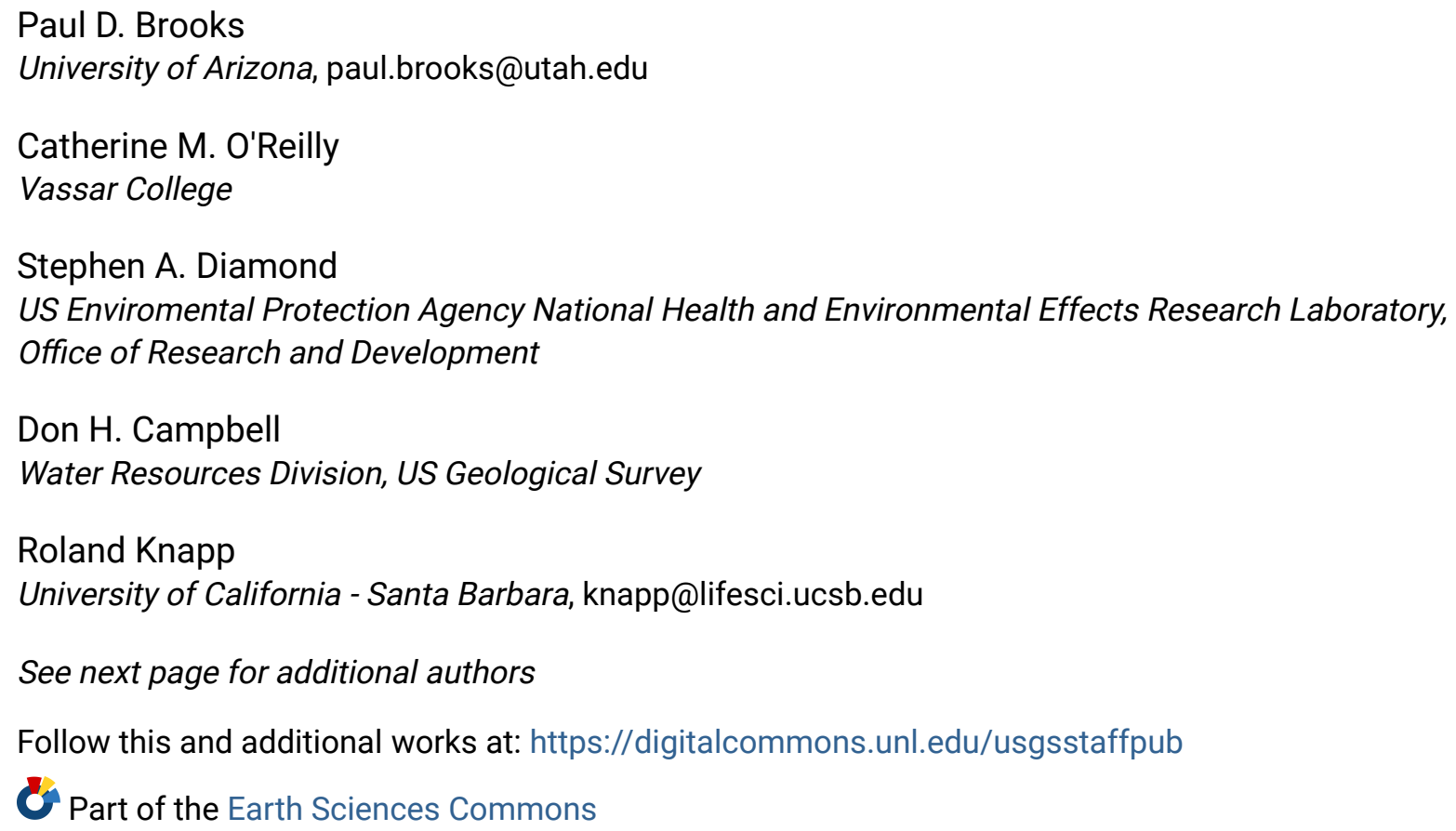

Brooks, Paul D.; O'Reilly, Catherine M.; Diamond, Stephen A.; Campbell, Don H.; Knapp, Roland; Bradford, David; Corn, Paul Stephen; Hossack, Blake; and Tonnessen, Kathy, "Spatial and Temporal Variability in the Amount and Source of Dissolved Organic Carbon: Implications for Ultraviolet Exposure in Amphibian Habitats" (2003). USGS Staff -- Published Research. 99.

https://digitalcommons.unl.edu/usgsstaffpub/99

This Article is brought to you for free and open access by the US Geological Survey at DigitalCommons@University of Nebraska - Lincoln. It has been accepted for inclusion in USGS Staff -- Published Research by an authorized administrator of DigitalCommons@University of Nebraska - Lincoln. 


\section{Authors}

Paul D. Brooks, Catherine M. O'Reilly, Stephen A. Diamond, Don H. Campbell, Roland Knapp, David Bradford, Paul Stephen Corn, Blake Hossack, and Kathy Tonnessen 


\title{
Spatial and Temporal Variability in the Amount and Source of Dissolved Organic Carbon: Implications for Ultraviolet Exposure in Amphibian Habitats
}

\author{
Paul D. Brooks, ${ }^{1}$ Catherine M. O'Reilly, ${ }^{2}$ Stephen A. Diamond, ${ }^{3}$ \\ Don H. Campbell, ${ }^{4}$ Roland Knapp, ${ }^{5}$ David Bradford, ${ }^{6}$ Paul Stephen Corn, ${ }^{7}$ \\ Blake Hossack, ${ }^{7}$ and Kathy Tonnessen ${ }^{8}$
}

\begin{abstract}
${ }^{1}$ Hydrology and Water Resources, University of Arizona, Tucson, Arizona 85721, USA; ${ }^{2}$ Department of Biology, Vassar College, Poughkeepsie, New york 12604, USA; ${ }^{3}$ US Enviromental Protection Agency National Health and Environmental Effects Research Laboratory, Office of Research and Development, 6201 Cogdon Blvd., Duluth,

Minnesota 55804, USA; ${ }^{4}$ Water Resources Division, US Geological Survey, MS 415, Lakewood, Colorado 80225, USA

${ }^{5}$ Sierra Nevada Aquatic Research Laboratory, University of California, HCR 79, Box 198, Crowley Lake, California 93546, USA ${ }^{6}$ US Enviromental Protection Agency, Office of Research and Development, P.O. Box 93478, Las Vegas, Nevada 89193-3478, USA ${ }^{7}$ Northern Rocky Mountain Science Center, US Geological Survey, Aldo Leopold Wilderness Research Institute,

790 E. Beckwith Ave., Missoula, Montana 59807, USA; ${ }^{8}$ National Park Service, Rocky Mountains Cooperative Ecosystem Studies Unit, School of Forestry, University of Montana, Missoula, Montana 59812, USA
\end{abstract}

\begin{abstract}
The amount, chemical composition, and source of dissolved organic carbon (DOC), together with in situ ultraviolet (UV-B) attenuation, were measured at $1-2$ week intervals throughout the summers of 1999, 2000, and 2001 at four sites in Rocky Mountain National Park (Colorado). Eight additional sites, four in Sequoia and Kings Canyon National Park/John Muir Wilderness (California) and four in Glacier National Park (Montana), were sampled during the summer of 2000. Attenuation of UV-B was significantly related to DOC concentrations over the three years in Rocky Mountain $\left(R^{2}=0.39, F=25.71, P<0.0001\right)$ and across all parks in $2000\left(R^{2}=0.44, F=38.25, P<0.0001\right)$. The relatively low $R^{2}$ values, however, reflect significant temporal and spatial variability in the specific attenuation per unit DOC. Fluorescence
\end{abstract}

Received 3 March 2003; accepted 25 August 2003; published online 31 July 2005.

*Corresponding author; e-mail: brooks@hwr.arizona.edu analysis of the fulvic acid DOC fraction (roughly 600-2,000 Daltons) indicated that the source of DOC significantly affected the attenuation of UV-B. Sites in Sequoia-Kings Canyon were characterized by DOC derived primarily from algal sources and showed much deeper UV-B penetration, whereas sites in Glacier and Rocky Mountain contained a mix of algal and terrestrial DOC-dominated sites, with more terrestrially dominated sites characterized by greater UV-B attenuation per unit DOC. In general, site characteristics that promoted the accumulation of terrestrially derived DOC showed greater attenuation of UV-B per unit DOC; however, catchment vegetation and soil characteristics, precipitation, and local hydrology interacted to make it difficult to predict potential exposure from DOC concentrations.

Key words: dissolved organic carbon; ultraviolet radiation; ultraviolet-B; amphibians; national parks. 


\section{INTRODUCTION}

Although water molecules are relatively transparent to the wavelengths of ultraviolet radiation (UVB, 280-320 nm) capable of damaging living tissue, dissolved and suspended substances within the water column may significantly attenuate the penetration of this potentially harmful radiation in aquatic ecosystems. Specifically, dissolved organic carbon (DOC) is the major control on the attenuation of UV-B radiation in water bodies with low turbidity (Schindler and others 1996; Williamson and others 1996). Attenuation of solar radiation by DOC is analogous to attenuation by ozone in the atmosphere; shorter, higher energy wavelengths are removed more effectively as light passes through the water column (Xenopoulos and others 2000). These wavelengths are responsible for causing damage to living organisms, including DNA lesions, erythema, and photosynthetic inhibition (Holm-Hansen .and others 1993; Blaustein and others 1994, 1997; Tietge and others 2001; Xenopoulos and others 2002). At moderate DOC concentrations $(5-10 \mathrm{mg} / \mathrm{L})$, it is typical for UV-B radiation to be attenuated two to three times more effectively than UV-A radiation and 10 times more effectively than visible radiation.

The potential for an increase in UV-B radiation due to thinning ozone to have a deleterious effect on amphibian populations in high-elevation water bodies has received considerable attention (Corn and Muths 2002; Corn 2003; Merila and others 2000). Recently, Kiesecker and others (2001) suggested that other types of climate change-specifically, a reduction in precipitation-may result in an increase in UV exposure for amphibians by reducing water depth in breeding pools during drought years. However, breeding by montane amphibians depends on the timing of snowmelt, and breeding is earlier in years with low snow accumulation (Corn and Muths 2002). Earlier breeding may reduce UV exposure due to both lower solar angle earlier in the year (Merila and others 2000; Corn and Muths 2002) and higher DOC concentrations after the spring flush of terrestrial DOC that characterizes these ecosystems (Hornberger and others 1994; Boyer and others 1997). Seasonal variability in both UV-B radiation and surface-water DOC concentrations, coupled with changes in amphibian breeding phenology, make it crucial to understand how changes in DOC concentration and composition affect potential exposure to UV-B radiation in a changing climate (Morris and others 1995; Laurion and others 1997; Crump and others 1999).
"Dissolved organic carbon" refers to a broad range of compounds ranging in size from one to several thousand carbon atoms, not all of which are capable of absorbing/attenuating UV-B radiation. Chemical analyses of DOC suggest that the vast majority of UV-B attenuation is due to compounds in the fulvic acid DOC fraction (Thurman 1985; Wetzel 1992; Scully and Lean 1994; McKnight and others 1997, 2001). Fulvic acids are characterized by a higher molecular weight and a more complex structure than the nonfulvic DOC fraction and may impart color to water that is often used to classify aquatic habitats (Thurman 1985; Wetzel 1992; Carpenter and others 1998; Crump and others 1999; Reche and others 1998). Although fulvic acids are formed from both algal and terrestrial precursors, algal fulvic acids tend to have much lower ability to attenuate UV-B, are more readily degraded, and consequently have a shorter residence time in the aquatic environment, suggesting that UV-B attenuation should be controlled primarily by the terrestrial fulvic acid content.

Spatial and temporal variability in the fraction of DOC that is capable of absorbing UV-B radiation may help explain why the concentration of DOC alone is not a consistent predictor of the depth to which UV-B penetrates (Laurion and others 1997; Curtis and Schindler 1997; Crump and others 1999). Because the chemical structures responsible for UV-B attenuation are found primarily in the terrestrially derived fulvic acid fraction of dissolved organic matter, the hydrologic characteristics of individual sites that control the delivery and residence time of terrestrial DOC in surface water are likely to exert significant control on the amount of photoreactive fulvic acid present in surface water. Specifically, precipitation events that have the ability to transport terrestrial DOC from surrounding soils to surface water and the hydrologic residence time of this DOC in individual water bodies are likely to have a strong influence on UV-B attenuation. The importance of the hydrologic connection between terrestrial and aquatic systems is demonstrated by reports that DOC in the lakes of Ontario has a higher specific absorbance in the spring than in midsummer (Crump and others 1999), likely due to the precipitation/snowmelt flush of terrestrial organic matter to surface water (Creed and Band 1998).

The objective of this work was to quantify the spatial and temporal variability in the concentration, composition, and source (terrestrial versus aquatic) of DOC and relate this variability to potential UV-B exposure in aquatic environments in three high-elevation national parks in the western 
Table 1. Physical Characteristics of the 12 Study Sites from Rocky Mountain National Park (Rocky), Glacier National Park (Glacier), and Sequoia-Kings Canyon National Park/John Muir Wilderness (Sequoia)

\begin{tabular}{|c|c|c|c|c|c|}
\hline Site & $\begin{array}{l}\text { Elevation } \\
(\mathrm{m})\end{array}$ & Physical Setting & $\begin{array}{l}\text { Maximum Depth } \\
(\mathrm{m})\end{array}$ & $\begin{array}{l}\text { Area } \\
\left(\mathrm{m}^{2}\right)\end{array}$ & Hydrologic Setting \\
\hline \multicolumn{6}{|l|}{ Rocky } \\
\hline Timber Creek Camp & 2,731 & Riparian & 1.2 & 90 & Drainage \\
\hline Glacier Basin & 2,618 & Meadow & 0.75 & 450 & Drainage \\
\hline Moraine Park & 2,451 & Meadow & 2 & 650 & Perched \\
\hline Kettle Tarn & 2,810 & Forest & 4 & 900 & Perched \\
\hline \multicolumn{6}{|l|}{ Glacier } \\
\hline Fern & 1,174 & Forest & 0.5 & 320 & Perched \\
\hline South Boundary & 1,357 & Forest & 1.0 & 1,500 & Perched \\
\hline Ole & 1,220 & Forest & 0.25 & 30 & Perched \\
\hline $2 \mathrm{Med} 2$ & 1,593 & Riparian & 1.0 & 3,600 & Drainage \\
\hline \multicolumn{6}{|l|}{ Sequoia } \\
\hline 10418 & 3,280 & Rock/talus & 16 & 66,862 & Drainage \\
\hline 11080 & 3,380 & Meadow & 0.5 & 296 & Perched \\
\hline 50255 & 3,206 & Sparse forest & 12 & 556,882 & Drainage \\
\hline 51500 & 3,230 & Rock/talus & 2.5 & 1,227 & Perched \\
\hline
\end{tabular}

United States. Because UV-B may increase as much as $19 \%$ per $1,000 \mathrm{~m}$ of elevation (Blumthaler and Ambach 1990; Blumthaler and others 1992), these high-elevation sites provide a natural high-stress environment where small changes in UV-B may have a significant impact on aquatic ecosystems. We hypothesized that spatial and temporal variability in the amount of photoreactive DOC has a large effect on the UV-B exposure to organisms within the water column. Specifically, we expected that (a) UV-B attenuation would be related to DOC concentration, (b) the fulvic acid DOC fraction would be a better predictor of UV-B attenuation than total DOC, (c) terrestrially derived DOC (that is, fulvic acids) would exhibit greater UV-B attenuation per unit DOC, and (d) hydrologic variability in the transport of terrestrial fulvic acids to surface water would result in temporal variability in UV-B attenuation.

\section{Methods and Site Descriptions}

Surface waters in Rocky Mountain National Park, Colorado (Rocky); Glacier National Park, Montana (Glacier); and Sequoia-Kings Canyon National Parks and the adjacent John Muir Wilderness, California (Sequoia) were sampled for DOC composition and concentration, inorganic chemistry, and the depth of UV-B penetration. The annual hydrologic cycle in these parks is dominated by snowmelt, with most of the accumulated terrestrial DOC being flushed to surface water once each spring (Hornberger and others 1994; Boyer and others 1997; Brooks and others 1999). Summer thunderstorms, however, have the potential to transport small amounts of terrestrial DOC to surface water during the summer as well as promote algal growth through increasing nutrient supply. The Sequoia sites are different from those in Rocky and Glacier in that most water bodies are surrounded by exposed bedrock rather than vegetated soils. The absence of well-developed soil and vegetation results in low amounts of terrestrial DOC that can be transported to surface water. These three parks encompass a broad range of DOC environments, and all receive relatively high levels of UV-B radiation $\left(124-171 \mu \mathrm{W} \mathrm{cm} \mathrm{cm}^{-2}\right.$ calculated and confirmed by nearby measurements) due to their high elevation (Blumthaler and others 1997).

After an initial screening of 27 sites in Rocky for DOC concentrations, inorganic chemistry, and hydrologic position, sampling was initiated during the summer of 1999 at four sites chosen to represent a range of physical and chemical environments found in amphibian habitats in the park (Table 1). The specific criteria for selection were (a) historical amphibian survey data, (b) variability between sites in DOC concentrations, (c) variability in hydrologic position, and (d) variability in surrounding vegetation and soils. Sampling was expanded to eight additional sites, four each in Glacier and Sequoia, in addition to the Rocky sites, during the summer of 2000. A 3rd year of sampling at the sites in Rocky was done in 2001 to continue the assessment of interannual variability. All water bodies were sampled 9-10 times between May and September of each year. Sites were selected to represent variability in the two biogeochemical 
Table 2. Dissolved Organic Carbon (DOC) Content and Characteristics with Associated UV-B Penetration ${ }^{\mathrm{a}}$ in Surface Waters of 12 Sites in Protected Areas of the Western United States

\begin{tabular}{|c|c|c|c|c|}
\hline Site & Total DOC $(\mathrm{mg} / \mathrm{L})$ & Fulvic Acid (mg/L) & Fluorescence Index & UV-B Penetration ${ }^{\mathrm{a}}(\mathrm{cm})$ \\
\hline \multicolumn{5}{|l|}{ Rocky } \\
\hline Timber Creek Camp & $9.2(4.5)$ & $5.8(3.0)$ & 1.48 & $11.2(7.6)$ \\
\hline Glacier Basin & $3.9(1.6)$ & $2.3(0.9)$ & 1.65 & $18.6(4.6)$ \\
\hline Moraine Park & $23.9(11.4)$ & $14.3(6.9)$ & 1.34 & $5.9(4.4)$ \\
\hline Kettle Tarn & $12.8(3.3)$ & $6.5(2.1)$ & 1.67 & $29(13.5)$ \\
\hline \multicolumn{5}{|l|}{ Glacier } \\
\hline Fern & $17.6(5.1)$ & $8.4(1.4)$ & 1.38 & 1.4 \\
\hline South Boundary & $10.2(6.4)$ & $6.3(5.3)$ & 1.58 & 20.1 \\
\hline Ole & $5.3(7.0)$ & $4.7(6.8)$ & 1.81 & 22.4 \\
\hline $2 \mathrm{Med} 2$ & $15.0(5.7)$ & $10.7(2.8)$ & 1.55 & 19.2 \\
\hline \multicolumn{5}{|l|}{ Sequoia } \\
\hline 10418 & $1.4(0.8)$ & $1.0(0.7)$ & 1.81 & $418(124)$ \\
\hline 11080 & $2.5(2.1)$ & $1.9(1.9)$ & 1.76 & $86.8(20.4)$ \\
\hline 50255 & $0.9(0.7)$ & $0.7(0.8)$ & 1.78 & $158(14.6)$ \\
\hline 51500 & $2.5(0.5)$ & $1.5(0.5)$ & 1.76 & $68(33.1)$ \\
\hline
\end{tabular}

characteristics most strongly related to UV-B penetration (a) the initial DOC concentration, which is strongly related to the surrounding landscape, and (b) the residence time of DOC in the water body, which is related to hydrologic position. The sites in all three parks generally represent a subset of those used by Diamond and others (2005) in their estimates of UV doses in six national parks.

Water samples were collected in 1-L amber glass bottles and immediately filtered through $0.45-\mu \mathrm{m}$ glass fiber filters. Both bottles and filters were precombusted for $4 \mathrm{~h}$ at $450^{\circ} \mathrm{C}$. Samples were kept as cool as possible in the field and then stored at $4^{\circ} \mathrm{C}$ on return to the lab. During at least two visits to each site, UV-B radiation (280-320 nm) was measured at the water surface and at multiple depths throughout the water column using a hand-held radiometer (Advanced Photonics, Irvine, CA 92614, USA or Macam, Livingston Scotland EH54 5PF calibrated annually by the manufacturer). Incoming radiation was measured within $2 \mathrm{~h}$ of solar noon and under clear-sky conditions. Most of the water bodies in these parks are characterized by low turbidity, and measurements were not made if episodic disturbances (for example, recent heavy rain, windstorm, large-animal wading) had occurred.

The fulvic acid DOC fraction was isolated in the lab by column chromatography using XAD- 8 resins to produce operationally defined hydrophobic/fulvic acid and hydrophilic fractions (Thurman and Malcolm 1981). Total DOC, hydrophobic/fulvic acid, and hydrophilic acids were analyzed subsequently on a Shimadzu 5050 TOC analyzer.
Additionally, fulvic acid fractions were analyzed using the method of McKnight and others (2001) to identify the source of the organic matter for one to six dates per site. Briefly, the fulvic acid sample was irradiated at $370 \mathrm{~nm}$ and emission was measured at 450 and $500 \mathrm{~nm}$. The ratio of emission at these wavelengths, termed the "fluorescence in$\operatorname{dex}^{\prime \prime}(\mathrm{FI})$, is indicative of the original carbon source (McKnight and others 2001). Fulvic acid derived from algal primary production possesses a 450:500 ratio close to 1.9 , whereas fulvic acids from terrestrial precursors have values closer to 1.3.

The hydrologic position of the sites was defined by physical characteristics and seasonal changes in inorganic chemistry. Ponds with no visible inlet and outlet that showed a doubling of acid-neutralizing capacity (ANC) and/or the sum of base cations over the summer, indicative of evapoconcentration of solutes, were classified as perched. Sites with relatively stable ANC and cation concentrations throughout the year, indicative of a constant input/flowthrough of groundwater, were classified as drainage. Major ions were measured on a Dionex ion chromatograph. Ammonium was determined using a flowthrough spectrophotometer using the phenolate reaction, and ANC was measured using a Gran titration (Gran 1952).

\section{RESUlts}

The concentration and composition of DOC varied spatially and temporally among the 12 sites (Table 2). Sites in Sequoia had lower DOC and fulvic 

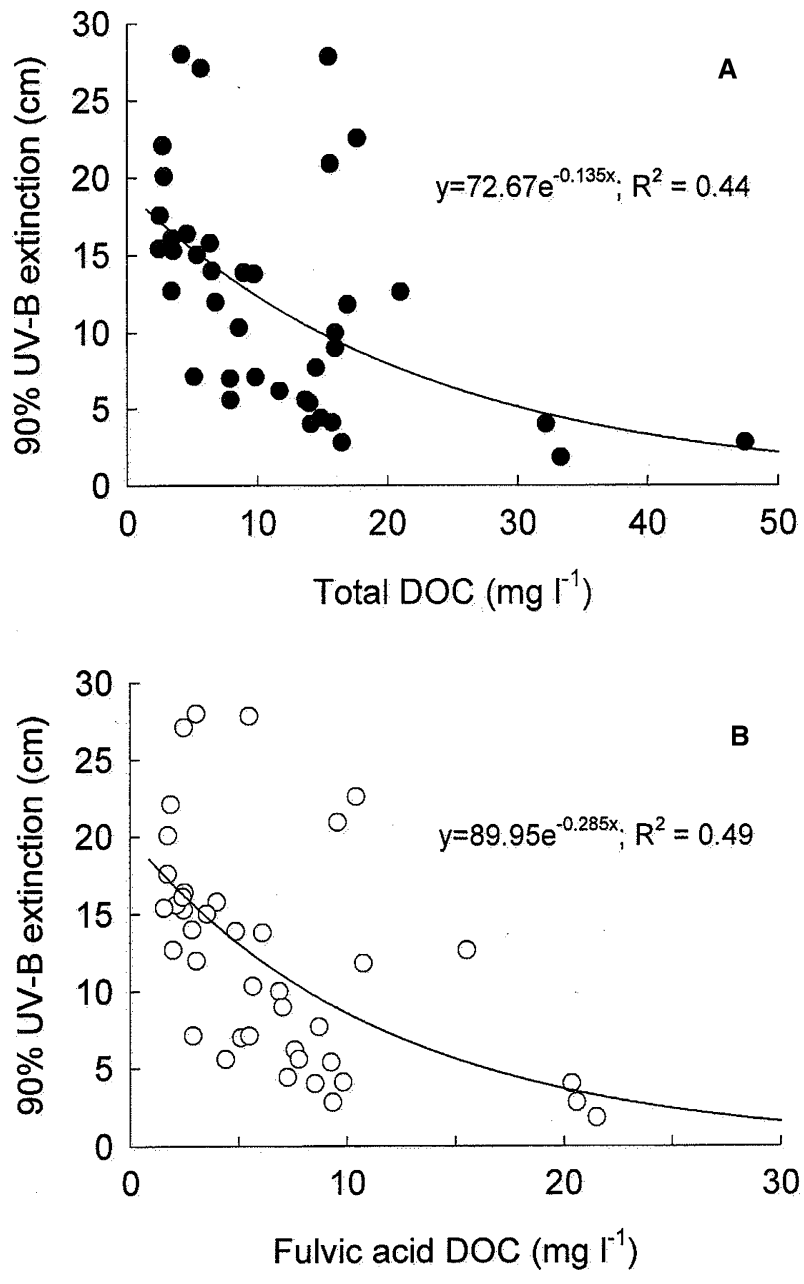

Figure 1. The relationships between A dissolved organic carbon (DOC) and $\mathbf{B}$ dissolved fulvic acid and ultravioletB (UV-B) attenuation in surface waters of Rocky Mountain National Park in 1999 through 2001. Each point represents one of 40 unique site-date combinations

acid concentrations than sites in Glacier and Rocky (analysis of variance [ANOVA], $n=86, F=13.9, P$ $<0.0001$ and $n=86, F=11.5, P<0.0001$ for DOC and fulvic acids, respectively). Surface waters in Glacier and Rocky had greater spatial variability in both total DOC and fulvic acid concentrations than did Sequoia. The penetration of UV-B radiation was greater in the low DOC waters of Sequoia than in the higher DOC water bodies in Rocky or Glacier (ANOVA, $n=43, F=13.9, P<0.0001$ ). Similarly, UV-B dose estimates generally were higher for aquatic environments in Sequoia than in Glacier or Rocky (Diamond and others 2005).

Concentrations of both DOC $\left(R^{2}=0.14\right.$, $F=25.71, P<0.0001$ ) (Figure $1 \mathrm{~A}$ ) and fulvic acid $\left(R^{2}=0.49, \quad \mathrm{~F}=21.84, \quad P<0.0001\right) \quad$ (Figure 1B) were significantly related to UV-B attenuation during the 3 years of measurements in Rocky.
Similarly, DOC concentrations were significantly related to UV-B attenuation at all three parks in 2000 (Figure 2). The predictive ability of DOC for UV attenuation was weakest $\left(R^{2}=0.16\right)$ in Sequoia, intermediate in Rocky $\left(R^{2}=0.40\right)$, and strongest $\left(R^{2}=0.67\right)$ in Glacier, indicative of a large amount of variability in the ability of dissolved organic matter in these headwater catchments to attenuate UV-B radiation.

The FI indicated a broader range of DOC sources to sites in Rocky and Glacier than in Sequoia. Fluorescence index values ranged from 1.33 to 1.81 for water bodies in Rocky and Glacier (Table 2); most sites were at the lower end of this range, indicating primarily terrestrial DOC sources. In contrast, the Sequoia sites had FI values ranging from 1.76-1.81 (Table 2), indicating a greater contribution of algal carbon to the DOC pool (ANOVA, $n=12, F=3.66, P=0.07$ ). The specific UV-B attenuation of the dissolved fulvic acids (calculated by dividing the $90 \%$ attenuation depth by the fulvic acid concentration) was related the source of organic matter in each pond or wetland (Figure 3). Sites with a terrestrial (lower) FI attenuated significantly more UV-B per mg fulvi acid $C$ than sites with higher FI values (specific UV$\mathrm{B}$ attenuation $=3 \mathrm{E}-09 \mathrm{e}^{13.547 \text { fulvic acid }} \mathrm{C} ; \mathrm{R}^{2}=0.75$; $F=173 ; P<0.0001)$.

The hydrological characteristics (perched or drainage) of individual sites, coupled with variability in precipitation, resulted in an additional source of variability in UV-B attenuation. Summer precipitation at the Beaver Meadows (National Atmospheric Deposition) Program (NADP) site in Rocky during 1999 was $340 \%$ higher than 2000 and $162 \%$ higher than 2001 (Figure 4). Higher precipitation amounts in 1999 were associated with lower fulvic acid concentrations (Figure 5) and significantly lower attenuation (deeper UV-B penetration) than in 2000 or 2001 (Figure 6) at the two sites located along drainages, Timber Creek and Glacier Basin. There were no significant differences in fulvic acid content at the perched sites, Moraine Park and Kettle Tarn, over the 3 years of the study (Figure 5). However, in contrast to the deeper UV$B$ penetration observed at the drainage sites in 1999, the perched sites were characterized by greater attenuation (shallower UV-B penetration) in 1999 than in 2000 or 2001 (Figure 6).

\section{Discussion}

Although both DOC and the fulvic acid DOC fraction were significantly related to UV-B attenuation, the strength of the relationships between total DOC 


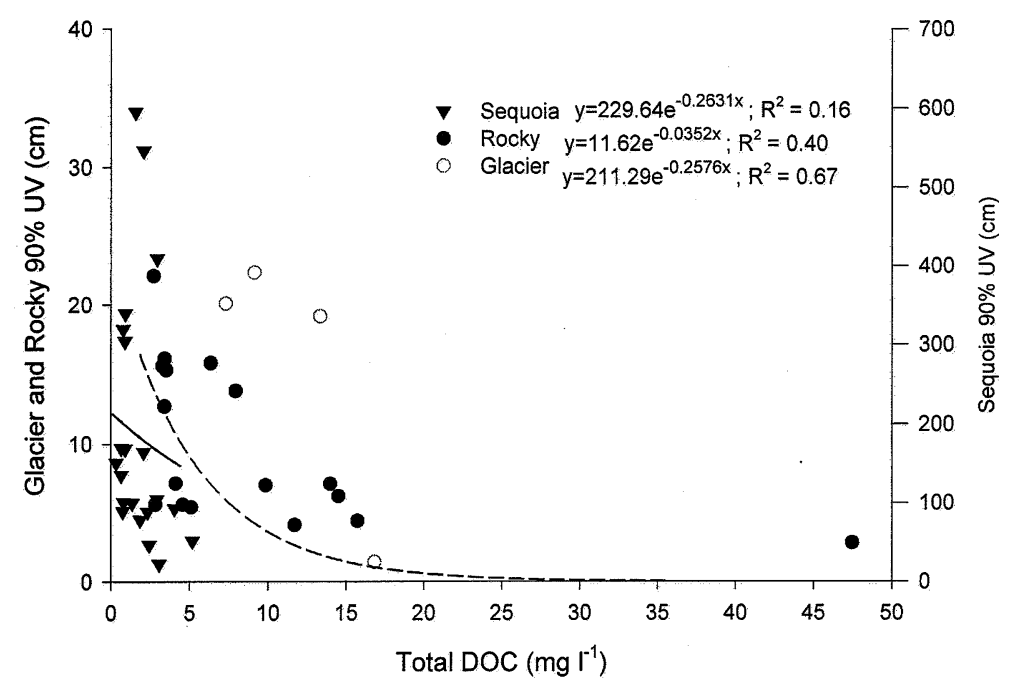

Figure 2. The relationships between dissolved organic carbon (DOC) and ultraviolet (UV) attenuation in surface waters from Rocky Mountain, Glacier, and Sequoia-Kings Canyon national parks in the summer of 2000. There were four unique site-date combinations for Glacier, 17 for Rocky, and 21 for Sequoia.

and extinction for these headwater catchments was much weaker than most previously reported values (Schindler and others 1996; Williamson and others 1996; Crump and others 1999; Bukaveckas and Robbins-Forbes 2000). Typically, only in waters with a high density of suspended algae or high total dissolved solids does the relationship between DOC and UV-B tend to weaken (Laurion and others 2000; Smith and others 2000). The sites in these parks, however, are low in dissolved solids and suspended algae, and care was taken to avoid sample collection or radiometer measurements after any disturbance that might increase particulates in suspension. Therefore, the results from these high-elevation sites indicate much higher spatial and temporal variability in the photoreactive UV-B attenuation properties of DOC among these three parks than would be expected based on previous research. Consequently, potential UV-B exposure may be highly variable in these systems as well.

The inability of the fulvic acid DOC fraction to provide a better prediction of UV-B attenuation was contrary to our initial hypotheses. Although the majority of photoreactive moieties are found in the fulvic acid DOC fraction (Thurman 1985; Wetzel 1992; Scully and Lean 1994; McKnight and others 1997; 2001; Laurion and others 1997; France and others 2000; Crump and others 1999; Hongve 1999), these compounds were not strong predictors of UV-B attenuation. Although fulvic acids originate from both terrestrial and algal sources, the structures capable of attenuating UV-B are found primarily in the terrestrial fulvic acid fraction, which is structurally more complex and consequently more resistant to degradation than aquatic fulvic acids. Our expectation was that these terrestrially derived fulvic acid structures would dominate the aquatic DOC pool and be a strong predictor for UV-B attenuation. However, seasonal variability in the source and residence time of terrestrial fulvic acids appears to be more important than the higher resistance to degradation when considering potential UV-B exposure. Seasonal variability in the ability of DOC to attenuate UV-B has been reported, with higher attenuation per unit DOC in the spring (Crump and others 1999; Bertilsson and Bergh 1999). Presumably, this higher attenuation in the spring is due to the large pulse of terrestrial organic matter that is transported to surface water during snowmelt (Hornberger and others 1994; Boyer and others 1997; McKnight and others 1997; Creed and Band 1998). For amphibians, the higher specific attenuation combined with lower solar angles, may greatly reduce the UV-B exposure of organisms that breed earlier in the season (Corn and Muths 2002).

The importance of the source of the dissolved fulvic acids to photoreactivity is highlighted by the relationship between specific UV-B attenuation and the FI (Figure 3). These differences in the source of DOC provide insight into the causes of spatial variability in the relationships between DOC and fulvic acids, and UV-B attenuation. In general, the amount of terrestrially derived DOC in surface water is strongly related to the soil organic carbon pools in the surrounding landscape (Hope and others 1997; Aitkenhead and others 1999; Aitkenhead and McDowell 2000). Poorly developed soils and large areas of bedrock in the area surrounding the Sequoia sites result in a reduced potential for terrestrial DOC transport to surface water. Consequently, the aquatic DOC pool at the Sequoia sites is dominated by algal sources with FI values ranging from 1.76 to 1.81 , similar to the average FI of 1.83 for eight desert oasis lakes in Antarctica 


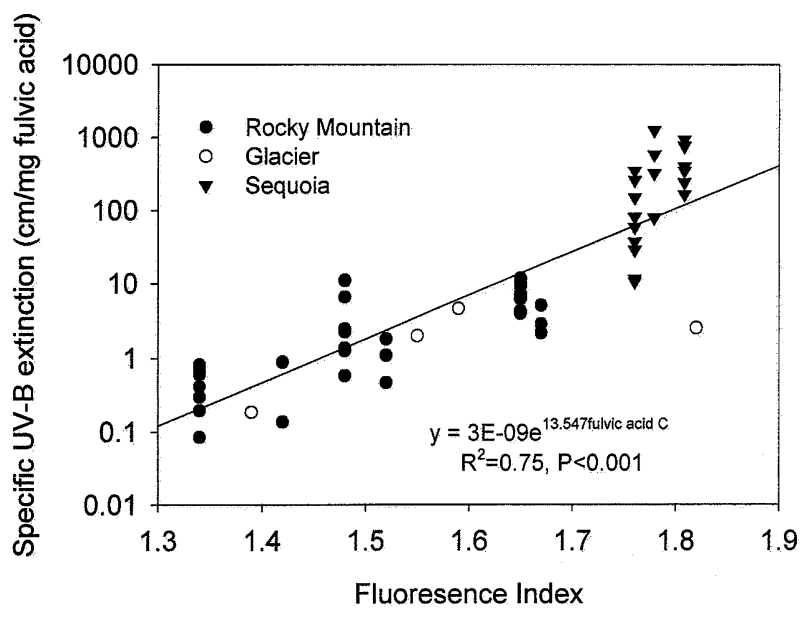

Figure 3. The relationship between the fluorescence index, an indicator of the precursor material for dissolved organic carbon and specific ultraviolet -B (UV-B) attenuation in Rocky Mountain, Glacier, and Sequoia-Kings Canyon National Parks during the summer of 2000. There were four unique site-date combinations for Glacier, 36 for Rocky, and 21 for Sequoia.

located in areas without a source of terrestrial DOC (McKnight and others 2001). The lack of a significant terrestrial component to the DOC pool is associated with much greater penetration of UV-B radiation per unit DOC or fulvic acid (Table 2). For example, DOC concentrations between 1 and 4 $\mathrm{mgL}^{-1}$ in Rocky and Glacier were associated with $90 \%$ UV-B attenuation depths of $10-30 \mathrm{~cm}$, whereas Sequoia attenuation depths at similar DOC concentrations were on the order of 100-600 cm. The limited ability of aquatically derived fulvic acids in Sequoia to attenuate UV-B radiation underscores the fact that DOC from algal precursors is not an effective screen for UV-B, whereas DOC from terrestrial sources contains a higher percentage of structures capable of absorbing UV-B (Thurman 1985; Bertilsson and Bergh 1999; Hongve 1999; Bertilsson and Tranvik 2000).

The amount of photoreactive DOC in these ponds was also related to interactions between local hydrology and interannual variability in precipitation. Perched sites are relatively closed systems where solutes accumulate, whereas drainage sites are open systems with much shorter hydrologic residence times. Like all these parks, the annual hydrologic cycle in Rocky is dominated by snowmelt, with most terrestrial DOC being flushed from soils to surface water during the spring (Hornberger and others 1994; Boyer and others 1997). Summer storms provide an additional, but typically much smaller, source of terrestrial DOC to surface waters. Annual, and especially spring/summer, precipita- tion in Rocky was higher in 1999 than in 2000 or 2001 (Figure 4). Research in nearby catchments indicates that the amount of potentially photoreactive DOC produced in the soils and subsequently available for transport is higher during years with greater precipitation (Brooks and others 1999). The combination of greater DOC production within the soil and larger amounts of with water from higher precipitation inputs likely explains why the perched sites, Moraine Park and Kettle Tarn, showed greater UV-B attenuation in 1999 than in 2000 or 2001, even though there were no significant differences in fulvic acid concentrations. Lower precipitation inputs in 2000 and 2001 resulted in less terrestrial DOC transport to surface water and lower specific UV-B attenuation per unit DOC, whereas a gradual drying of these areas over the course of the summer resulted in highly variable DOC concentrations. In contrast, higher precipitation in 1999 resulted in lower attenuation at the drainage sites, Glacier Basin and Timber Creek, due to greater water input and a shorter hydrologic residence time for terrestrial DOC and fulvic acids in the wetter year.

The potential exposure of aquatic organisms to UV-B in these headwater ecosystems varied both spatially and temporally due to controls on the delivery and residence time of terrestrial DOC in surface water. The two primary causes of spatial variability were the characteristics of the surrounding soils (the sources of DOC) and local hydrologic flowpaths. Water bodies surrounded by well-developed soils, as found in much of Rocky or Glacier, generally showed greater specific UV-B attenuation per unit DOC. In contrast, poorly developed soils in Sequoia resulted in little terrestrial DOC available to be transported to surface water, an aquatic DOC pool dominated by algal sources, and higher UV-B exposure. Consequently, a given concentration of DOC provided much greater protection to the organisms in Rocky or Glacier than those in Sequoia. Local hydrologic flowpaths resulted in an additional source of spatial variability by controlling the residence time of terrestrial DOC in individual water bodies. Sites that accumulated terrestrial DOC showed greater UV-B attenuation than sites that were continually flushed by groundwater. Temporal variability in potential UV-B exposure was related to precipitation with wet years resulting in greater transport of terrestrial DOC to surface water (Boyer and others 1997; Brooks and others 1999). However, local hydrologic flowpaths determined whether the increased input of terrestrial DOC accumulated, resulting in greater UV-B attenuation (as in per- 

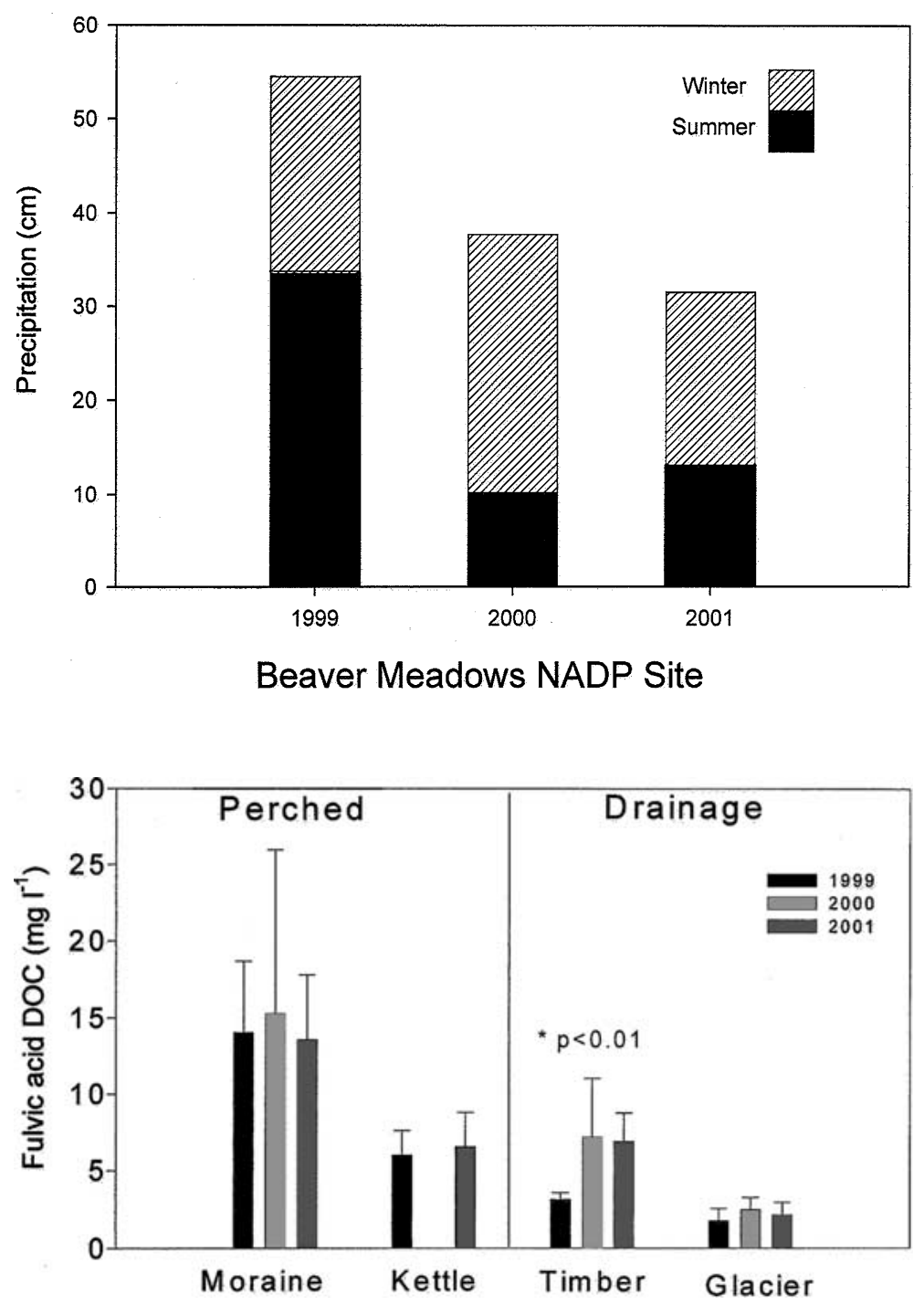

Figure 4. Annual and summer (May through August) precipitation totals at the Beaver Meadows (2,490 m) National Atmospheric Deposition Program (NADP) site in Rocky Mountain National Park.
Figure 5. Variability in the fulvic acid dissolved organic carbon (DOC) concentration at the four intensively monitored sites in Rocky Mountain National Park during 1999, 2000, and 2001. Values are the mean of nine samples between May and September; error bars represent \pm 1 SD. Statistical significance between years was calculated using one-way analysis of variance. ched sites), or was flushed, resulting in greater potential UV-B exposure (as in drainage sites). Consequently, interannual variability in precipitation may result in a cycle whereby increased UV-B stress alternates between drainage sites in wet years and perched sites in drier years.

\section{SUMmary}

Although the central role that DOC plays in attenuating UV-B radiation in aquatic environments is well established (for example, see Schindler and others 1996; Williamson and others 1996), this work emphasizes the emerging importance of the terrestrial DOC fraction in controlling potential UV-B exposure (Laurion and others. 2000; Williamson and others 2001; Imai and others 2001). For a particular habitat, variability in the terrestrial DOC content can be evaluated by examining physical characteristics of the surrounding catchment. Specifically, knowledge of both surrounding soil characteristics and hydrologic flowpaths could be applied to determine the terrestrial DOC content and whether a site is likely to be characterized by relatively high or low potential UV-B exposure. Temporal variability in terrestrial DOC content and potential UV-B exposure is more difficult to evaluate. Of all the factors that control UV-B exposure in aquatic environments, only DOC concentrations and composition show rapid, major changes in response to seasonal, interannual, and directional variability in climate. Specifically, changes in precipitation may have a large effect on the delivery of terrestrial DOC to surface water environments, but local hydrologic flowpaths determine the residence time of this DOC and whether a particular site will experience an increase or decrease in potential UVB exposure. 


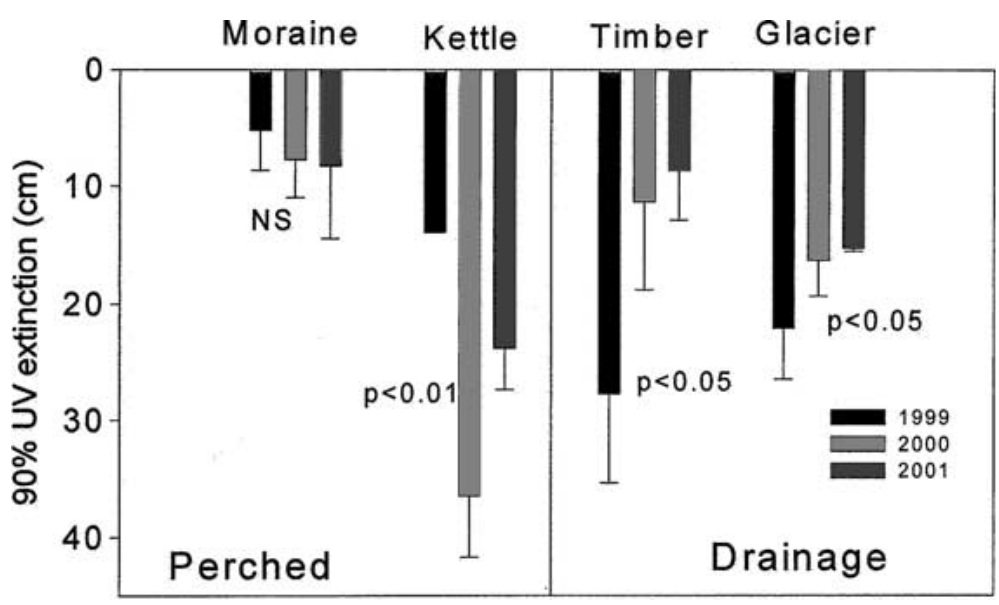

Figure 6. Variability in ultraviolet (UVB) attenuation at the four intensively monitored sites in Rocky Mountain National Park during a relatively wet year (1999), and two relatively dry years (2000 and 2001). Values are the mean of nine samples between May and September; error bars represent \pm SD. Statistical significance between years was calculated using a one-way analysis of variance.

\section{ACKNOWLEDGMENTS}

We thank the National Park Service, Rocky Mountain National Park, and the Institute of Arctic and Alpine Research, Colorado University at Boulder, for logistical support. We are grateful to Eran Hood, Ken Czarnowski, Mary Kay Watry, Diane McKnight, and George Aiken for valuable discussions regarding this work. Two anonymous reviewers also provided valuable comments on the manuscript.

\section{REFERENCES}

Aitkenhead JA, Hope D, Billett MF. 1999. The relationship between dissolved carbon in stream water and soil organic carbon pools at different spatial scales. Hydrol Proc 13:1289-302.

Aitkenhead JA, McDowell WH. 2000. Soil C:N ratio as a predictor of annual riverine DOC flux at local and global scales. Global Biogeochem Cycles 14:127-38.

Bertilsson S, Bergh S. 1999. Photochemical reactivity of XAD-4 and XAD-8 adsorbable dissolved organic compounds from humic waters. Chemosphere 39:2289-300.

Bertilsson S, Tranvik LJ. 2000. Photochemical transformation of dissolved organic matter in lakes. Limnol Oceanog 45:753-62.

Blaustein AR, Hoffman PD, Hokit DG, Kiesecker JM, Walls SC, Hayes JB. 1994. Uv repair and resistance to solar uv-B in amphibian eggs—a link to population declines. Proc Nat Acad Sci USA 91:(5)1791-5.

Blaustein AR, Kiesecker JM, Chivers DP, Anthony RG. 1997. Ambient UV-B radiation causes deformities in amphibian embryos. Proc Nat Acad Sci USA 94:(25)13735-7.

Blumthaler M, Ambach W. 1990. Indication of increasing solar ultraviolet-B radiation flux in alphine regions. Science 248:(4952)206-8.

Blumthaler M, Ambach W, Rehwald W. 1992. Solar uv-a and uv-B radiation fluxes at alpine stations at different altitudes. TheoreAppl Climatol 46:39-44.

Blumthaler M, Ambach W, Ellinger R. 1997. Increase in solar UV radiation with altitude. J Photochem Photobio B 39:(2) 130-4.
Boyer EW, Hornberger GM, Bencala KE, McKnight DM. 1997. Response characteristics of DOC flushing in an alpine catchment. Hydrol Process 11:1635-47.

Brooks PD, McKnight DM, Bencala KE. 1999. The relationship between soil heterotrophic activity, soil dissolved organic carbon (DOC) leachate, and catchment-scale DOC export in headwater catchments. Water Resour Res 35:1895-902.

Bukaveckas PA, Robbins-Forbes M. 2000. Role of dissolved organic carbon in the attenuation of photosynthetically active and ultraviolet radiation in Adirondack lakes. Freshwater Biol 43:339-54.

Carpenter SR, Cole JJ, Kitchell JF, Pace ML. 1998. Impact of dissolved organic carbon, phosphorus, and grazing on phytoplankton biomass and production in experimental lakes. Limnol Oceanog 43:73-80.

Corn PS. 2003. Amphibian breeding and climate change: importance of snow in the mountains. Conserv Biol 7:622-5.

Corn PS, Muths E. 2002. Variable breeding phenology affects the exposure of amphibian embryos to ultraviolet radiation. Ecology 83:2958-63.

Creed IF, Band LE. 1998. Export of nitrogen from catchments within a temperate forest: evidence for a unifying mechanism regulated by variable source area dynamics. Water Resour Res 34:3105-120.

Crump D, Lean D, Berrlill M, Coulson D, Toy L. 1999. Spectral irradiance in pond water: influence of water chemistry. Photochem Photobiol 70:893-901.

Curtis PJ, Schindler DW. 1997. Hydrologic control of dissolved organic order Precambrian Shield lakes. Biogeochemistry 36:125-38.

Diamond SA, Trenham, PC Adams MJ, Hossack BR, Knapp RA, Stark SL, Bradford D, Corn PS, Czarnowski K, Brooks PD, Fagre D, Breen B, Detenback N, Tonnessen K. 2005. Estimated Ultraviolet Radiation Doses in Wetlands in Six National Parks. In Press, Ecosystems.

France R, Steedman R, Lehman R, Peters R. 2000. Landscape modification of DOC concentration in boreal lakes; implications for UV-B sensitivity. Water Soil Air Pollu 122:153-62.

Gran G. 1952. Determination of the equivalence point in Potentiometric titrations, Part 2. Analyst 77:661-71.

Holm-Hanse O, Lubin D, Helbling EW. 1993. Ultraviolet radiation and its effect on organisms in aquatic environments. In: 
Young AR, Bjorn LO, Moan J, Nultsch W, Eds. Environmetal UV photobiology. New York: Plenum Press. p 379-418.

Hongve D. 1999. Production of dissolved organic carbon in forested catchments. J Hydrol 224:91-9.

Hope D, Billett MF, Milne R, Brown TAW. 1997. Exports of organic carbon in British rivers. Hydrol Proc 11:325-44.

Hornberger GM, Bencala KE, McKnight DM. 1994. Hydrological controls on dissolved organic carbon during snowmelt in the Snake River near Montezuma, Colorado. Biogeoehemistry 25:147-65.

Imai A, Fukushima T, Matsushige K, Kim YH, Choi K. 2001. Fractionation and characterization of dissolved organic matter in a shallow eutrophic lake, its inflowing rivers, and other organic matter sources. Water Res 35:(17)4019-28.

Kiesecker JM, Blaustein AR, Belden JM. 2001. Complex causes of amphibian population declines. Nature 410:(6829)681-4.

Laurion I, Vincent WF, Lean DRS. 1997. Underwater ultraviolet radiation: Development of spectral models for northern high latitude lakes. Photochemistry and Photobiology 65:107-114.

Laurion I, Ventura M, Catalan J, Psenner R, Sommaruga R. 2000. Attenuation of ultraviolet radiation in mountain lakes: Factors controlling the among- and within-lake variability. Limnology and Oceanography 45:1274-1288.

McKnight DM, Harnish R, Wershaw RL, Baron JS, Schiff S. 1997. Chemical characteristics of particulate, colloidal and dissolved organic material in Loch Vale Watershed, Rocky Mountain Nationa Park. Biogeochemistry 36:99-124.

McKnigh DM, Boyer EW, Westerhoff PK, Doran PT, Kulbe T, Andersen DT. 2001. Spectrofluorometric characterization of dissolved organic matter for indication of precursor organic material and aromaticity. Limnol Oceanogr 46:38-48.

Merilal M, Pahkda M, Johanson U. 2000. Increased ultraviolet-B radiation, climate change, and latitudinal adaptation $-\mathrm{a}$ frog perspective. Ann Zool Fennici 37:129-34.

Morris DP, Zagarese H, Williamson CE, Balseiro EG, Hargreaves BR, Modenutti B, Moeller R, et al. 1995. The attentuation of solar UV radiation in lakes and the role of dissolved organic carbonLimnol Oceanog 40:1381-91.
Reche I, Pace ML, Cole JJ. 1998. Interactions of photobleaching and inorganic nutrients in determining bacterial growth on colored dissolved organic carbon. Microb Ecology 36:270-80.

Schindler DW, Curtis PJ, Parker BR, Stainton MP. 1996. Consequences of climate warming and lake acidification for UV-B penetration in North American boreal lakes. Nature 379:705-8.

Scully NM, Lean DRS. 1994. The attenuation of UV radiation in temperate lakes. Arch Hydrobiol 43:135-44.

Smith GR, Waters MA, Rettig JE. 2000. Consequences of embryonic UV-B exposure for embryos and tadpoles of the plains leopard frog. Conserv Biol 14:1903-7.

Thurman EM. 1985. Organic geochemistry of natural waters Dordrecht [Netherlands]: Martinus Nijhoff/Dr W Junk.

Thurman EM, Malcolm RL. 1981. Pregarative isolation of aquatic humic substances. Environ Sci Technol 15:463-6.

Tietge JE, Diamond SA, Ankley GT, Defoe DL, Holcombe GW, Jensen KM, Degitz SJ, others . 2001. Ambient solar UV radiation causes mortality in larvae of three species of Rana under controlled exposure conditions. Photochem Photobiol 74:(2)261-8.

Wetzel RG. 1992. Gradient-dominated ecosystems - sources and regulatory functions of dissolved organic-matter in freshwater ecosystems. Hydrobiologia 229:181-98.

Williamson CE, Stemberger RS, Morris DP, Frost TM, Paulsen SG. 1996. Ultraviolet radiation in North American lakes: attenuation estimates from DOC measurements and implications for plankton communities. Limnol Oceanogr 41:1024-34.

Williamson CE, Olson OG, Lott SE, Walker ND, Engstrom DR, Hargreaves BR, 2001. Ultraviolet radiation and zooplankton community structure following deglaciation in Glacier Bay, Alaska. Ecology 82: 1748-1760.

Xenopoulos MA, Prairie YT, Bird DF. 2000. Influence of ultraviolet-B radiation, stratospheric ozone variability, and thermal stratification on the phytoplankton biomass dynamics in a mesohumic lake. Can J Fish Aquat Sci 57:600-9.

Xenopoulos MA, Frost PC, Elser JJ. 2002. Joint effects of UV radiation and phosphorus supply on algal growth rate and elemental composition. Ecology 83:(2)423-35. 